\title{
Umbu Fruit Peel as Source of Antioxidant, Antimicrobial and $\alpha$-Amylase Inhibitor Compounds
}

\author{
Leilson de Oliveira Ribeiro ${ }^{1, *(\mathbb{C})}$, Beatriz Pereira de Freitas ${ }^{2}$, Carolline Margot Albanez Lorentino ${ }^{3}$, \\ Heloisa Freire Frota ${ }^{3}$, André Luis Souza dos Santos ${ }^{3}{ }^{(0}$, Davyson de Lima Moreira ${ }^{4}$, Bruno Sérgio do Amaral ${ }^{5}$, \\ Eliane Przytyk Jung ${ }^{1} \mathbb{D}$ and Claudete Norie Kunigami ${ }^{1}$
}

1 Laboratory of Organic and Inorganic Chemical Analysis, National Institute of Technology, Rio de Janeiro 20081-312, Brazil; eliane.jung@int.gov.br (E.P.J.); claudete.kunigami@int.gov.br (C.N.K.)

2 Faculty of Chemical Engineering, Federal University of Fluminense, Niterói 24210-240, Brazil; beatrizzfreitas11@gmail.com

3 Laboratory for Advanced Studies of Emerging and Resistant Microorganisms, Federal University of Rio de Janeiro, Rio de Janeiro 21941-902, Brazil; carolline.margot@gmail.com (C.M.A.L.); heloisafreiref@gmail.com (H.F.F.); andre@micro.ufrj.br (A.L.S.d.S.)

4 Laboratory of Natural Products, Rio de Janeiro Botanical Garden Research Institute, Rio de Janeiro 22460-030, Brazil; davysonmoreira@jbrj.gov.br

5 Federal Institute of Education, Science and Technology of São Paulo, São Paulo 05110-000, Brazil; bruno.sergio90@gmail.com

* Correspondence: leilson.oliveira@int.gov.br

Citation: Ribeiro, L.d.O.; de Freitas, B.P.; Lorentino, C.M.A.; Frota, H.F.; dos Santos, A.L.S.; Moreira, D.d.L.; do Amaral, B.S.; Jung, E.P.; Kunigami, C.N. Umbu Fruit Peel as Source of Antioxidant, Antimicrobial and $\alpha$-Amylase Inhibitor Compounds. Molecules 2022, 27, 410. https:// doi.org/10.3390/molecules27020410

Academic Editors:

Francesco Cacciola and

Urszula Gawlik-Dziki

Received: 11 December 2021

Accepted: 6 January 2022

Published: 9 January 2022

Publisher's Note: MDPI stays neutral with regard to jurisdictional claims in published maps and institutional affiliations.

Copyright: (C) 2022 by the authors. Licensee MDPI, Basel, Switzerland. This article is an open access article distributed under the terms and conditions of the Creative Commons Attribution (CC BY) license (https:// creativecommons.org/licenses/by/ $4.0 /)$.

\begin{abstract}
Herein, the extraction of bioactive compounds from umbu fruit peel was optimized using thermal-assisted solid-liquid extraction. In parallel, antioxidant, antimicrobial, and inhibitory effects against $\alpha$-amylase of optimized extract were also evaluated. The combination of operational conditions including the temperature $\left(32-74{ }^{\circ} \mathrm{C}\right)$, ethanol concentration (13-97\%), and solid/liquid ratio $(1: 10-1: 60 ; w / v)$ was employed using a rotational central composite design for optimization. The extracts were evaluated for total phenolic compounds (TPC), total flavonoid compounds (TFC) and antioxidant capacity by $\mathrm{ABTS}^{\bullet+}, \mathrm{DPPH}^{\bullet}$ and FRAP assays. The bioactive profile of the optimized extract was obtained by ultra-performance liquid chromatography coupled to quadrupole/timeof-flight mass spectrometry in electrospray ionization in both negative and positive modes. The statistically evaluated results showed that the optimal operational conditions for the recovery of bioactive compounds from umbu fruit peel included $74{ }^{\circ} \mathrm{C}, 37 \%$ ethanol, and a solid-liquid ratio of 1:38. Under these conditions, the obtained values were $1985 \mathrm{mg} \mathrm{GAE} / 100 \mathrm{~g}, 1364 \mathrm{mg} \mathrm{RE} / 100 \mathrm{~g}$, $122 \mu \mathrm{mol} \mathrm{TE} / \mathrm{g}, 174 \mu \mathrm{mol} / \mathrm{TE} \mathrm{g}$ and $468 \mu \mathrm{mol} \mathrm{Fe} \mathrm{F}^{2+} / \mathrm{g}$ for TPC, TFC, ABTS ${ }^{\bullet+}$, DPPH ${ }^{\bullet}$, and FRAP assays, respectively. In addition, the optimized extract was effective against Gram-positive and Gram-negative bacteria (MBC ranged from 0.060 to $0.24 \mathrm{mg} \mathrm{GAE} / \mathrm{mL}$ ), as well as it was effective to inhibit $\alpha$-amylase ( $\mathrm{IC}_{50}$ value of $0.076 \mathrm{mg} \mathrm{GAE} / \mathrm{mL}$ ). The optimized extract showed to be mainly constituted by phenolic acids and flavonoids.
\end{abstract}

Keywords: Spondias tuberosa; umbu waste; extraction optimization; mass spectrometry; enzyme activity; antibacterial activity

\section{Introduction}

Native fruits from Brazil have received attention in recent years for being sources of compounds of great technological and health interest. Fruits such as umbu, camucamu and juçara are sources of vitamin $C$ and phenolic compounds, for example $[1,2]$. Umbu fruit from Brazilian semi-arid regions contains bioactive compounds such as rutin, quercetin, carotenoids, and vitamin C, as reported by Ribeiro et al. [3]. This rich composition confers relevant antioxidant potential to fruit. In addition to being a fruit rich in bioactive compounds, umbu fruit plays an important socio-economic role, since it provides and 
increases the income of small and medium producers from the semi-arid region of Brazil. It is estimated that 7765 tons of this fruit were produced in 2018 [4], also being marketed as frozen pulp [5].

The processing of fruits generates a large volume of waste, mainly composed of peels, seeds and stones. Nowadays, it is well-known that waste from fruit processing may be rich in compounds with high added value. Thus, its use for the recovery of antioxidant and/or colorant compounds has been evaluated [6]. Grape pomace, for example, has been extensively evaluated for this purpose mainly due to its antioxidant potential, which increases antioxidant capacity of developed products and improves their shelf-life [7].

Considering umbu fruit, the peel and seed have already been evaluated for composition in macro and micronutrients and bioactive compounds. Ribeiro et al. [3] reported that the fruit peel presented contents of $1775 \mathrm{mg} / 100 \mathrm{~g}$ and $2751 \mu \mathrm{g} / 100 \mathrm{~g}$ for total phenolic compounds and total carotenoids, respectively, flavonoids such as rutin and quercetin being identified. $\beta$-carotene, zeinoxanthin, and $\beta$-cryptoxanthin were highlighted among the carotenoids. The fruit seed was evaluated by Dias et al. [8]. According to those authors, the seed oil was composed of palmitic, stearic, oleic, linoleic and linolenic fatty acids, with high content of unsaturated fatty acids (70-73\%). The authors also pointed out that obtained extracts of seeds were rich in phenolic compounds. Omena et al. [9] reported that the umbu fruit fractions, pulp, peel and seed, did not present cytotoxicity in assays using sheep corneal epithelial cells. In addition, phytochemical screening showed the presence of phenols, tannins, anthraquinones, anthrones, coumarins, triterpenoids and steroids in fruit peels extracted using 95\% hydroethanolic solution (qualitative assays). The antioxidant activity of this extract was also evaluated using a peroxyl radical-mediated lipid peroxidation membrane model, being observed that umbu fruit peel and seed extracts provided more than $95 \%$ protection of the membrane for $15 \mathrm{~min}$. These results were considered better than those obtained by positive controls (Trolox, vitamin C and resveratrol). Cangussu et al. [10] evaluated the potential of peel flours of mature and semi-mature umbu fruit as a source of bioactive compounds, highlighting the presence of trigonelline, an alkaloid with bioactive activities. The authors also evaluated the bioaccessibility of total extractable phenolics, flavonoids, and tannins of umbu fruit peel flour, suggesting that umbu fruit peel flour can be used in food products to replace other flours with lower nutritional and functional values. In this way, data demonstrate the potential of the processing waste of umbu fruit to obtain new products and/or bioproducts. Despite that, to the best of our knowledge, the optimal conditions for the recovery of bioactive compounds from fruit peel have not yet been optimized in order to provide technological approach to obtain a bioactive compoundrich extract with potential application by food and cosmetic industries, as in the following examples. An extract of siriguela fruit peel was used as an active ingredient in the formulation of a sunscreen. Silva et al. [11] reported that the extract composed of dicaffeoylglucose, hexahydroxydiphenoyl-galloyl-glucose, galloyl-bis-hexahydroxydiphenoyl-glucose, rutin, and quercetin (phenolic compounds) promoted protection against UVB ray in a sunscreen formulation at 30\% of extract. Extracts of fruit peels also have been used to enrich food films and coatings, since bioactive compounds can exhibit antimicrobial action, which help maintain the postharvest quality of fruits as reported by Gull et al. [12]. Their results showed that apricot fruit treated with nanochitosan coating added with $1 \%$ of pomegranate peel extract significantly reduced decay percentage, weight loss, effectively retained antioxidant activity, ascorbic acid, kept titratable acidity and firmness at a higher level than untreated fruit, as well as significantly inhibited total psychrophilic bacterial count, yeast and mold count during storage at $4{ }^{\circ} \mathrm{C}$ for 30 days.

Thus, the present work aimed to optimize the extraction of bioactive compounds from the umbu fruit peel and evaluate phytochemical profile of the optimized extract by UPLC-qTOF/MS (ultra-performance liquid chromatography coupled to quadrupole/timeof-flight mass spectrometry). Additionally, the antioxidant effect was evaluated, as well as the effect of the optimized extract against clinically relevant microorganisms and enzymatic activity of $\alpha$-amylase. 


\section{Results and Discussion}

\subsection{Effect of Independent Variables}

It was observed that umbu fruit peel provided antioxidant extracts by different assays as well as being rich in phenolic compounds, as summarized in Table 1. The TPC content changed from $525 \mathrm{mg} / 100 \mathrm{~g}$ to $1986 \mathrm{mg} / 100 \mathrm{~g}$, showing the strong influence of the extraction temperature, extractive solution, and solid-liquid ratio factors. The highest value for this response was obtained when higher extraction temperatures were employed. This pattern was also observed for TFC content, whose maximum value was $1513 \mathrm{mg} / 100 \mathrm{~g}$. Our results were superior to data reported by Ribeiro et al. [3], who found $1775 \mathrm{mg} / 100 \mathrm{~g}$ of TPC for umbu fruit peel extracted using $70 \%$ acetone (analytical extraction). In addition, those authors reported the presence of quercetin and rutin in this fraction of the fruit. It corroborates the use of TFC content as a response in our extraction study.

Table 1. Real and coded values of the independent variables employed to recover the bioactive compounds from umbu peels and total phenolic (TPC) and flavonoids (TFC) compounds and antioxidant capacity values of the extracts.

\begin{tabular}{|c|c|c|c|c|c|c|c|c|}
\hline \multirow{2}{*}{ Trials } & Temperature & Ethanol & Solid-Liquid Ratio & TPC $^{1}$ & TFC $^{2}$ & \multirow{2}{*}{$\mathrm{ABTS}^{\bullet+3}$} & \multirow{2}{*}{$\mathrm{DPPH}^{\bullet} 3$} & \multirow{2}{*}{ FRAP $^{4}$} \\
\hline & $\left({ }^{\circ} \mathrm{C}\right)$ & $(\%)$ & $(\mathrm{g} / \mathrm{mL})$ & & & & & \\
\hline 1 & $40(-1)$ & $30(-1)$ & $1: 20(-1)$ & 1280 & 925 & 74 & 95 & 319 \\
\hline 2 & $40(-1)$ & $30(-1)$ & $1: 50(+1)$ & 1644 & 1015 & 83 & 136 & 364 \\
\hline 3 & $40(-1)$ & $80(+1)$ & $1: 20(-1)$ & 603 & 692 & 25 & 49 & 150 \\
\hline 4 & $40(-1)$ & $80(+1)$ & $1: 50(+1)$ & 811 & 700 & 25 & 82 & 130 \\
\hline 5 & $65(+1)$ & $30(-1)$ & $1: 20(-1)$ & 1593 & 1203 & 88 & 113 & 443 \\
\hline 6 & $65(+1)$ & $30(-1)$ & $1: 50(+1)$ & 1677 & 1207 & 101 & 163 & 448 \\
\hline 7 & $65(+1)$ & $80(+1)$ & $1: 20(-1)$ & 731 & 867 & 34 & 65 & 180 \\
\hline 8 & $65(+1)$ & $80(+1)$ & $1: 50(+1)$ & 850 & 877 & 37 & 96 & 246 \\
\hline 9 & $32(-1.68)$ & $55(0)$ & $1: 35(0)$ & 1231 & 847 & 58 & 105 & 289 \\
\hline 10 & $74(+1.68)$ & $55(0)$ & $1: 35(0)$ & 1986 & 1513 & 109 & 162 & 504 \\
\hline 11 & $53(0)$ & $13(-1.68)$ & 1:35 (0) & 1315 & 906 & 74 & 126 & 348 \\
\hline 12 & $53(0)$ & $97(+1.68)$ & $1: 35(0)$ & 525 & 646 & 9 & 51 & 119 \\
\hline 13 & $53(0)$ & $55(0)$ & $1: 10(-1.68)$ & 1075 & 1121 & 61 & 71 & 321 \\
\hline 14 & $53(0)$ & $55(0)$ & $1: 60(+1.68)$ & 1652 & 1038 & 74 & 160 & 442 \\
\hline $15(\mathrm{CP})$ & $53(0)$ & $55(0)$ & $1: 35(0)$ & 1479 & 1055 & 73 & 121 & 316 \\
\hline $16(\mathrm{CP})$ & $53(0)$ & $55(0)$ & $1: 35(0)$ & 1379 & 1087 & 72 & 125 & 346 \\
\hline $17(\mathrm{CP})$ & $53(0)$ & $55(0)$ & $1: 35(0)$ & 1405 & 1186 & 77 & 128 & 364 \\
\hline
\end{tabular}

$\mathrm{CP}$-Central point. ${ }^{1}$ Results expressed as mg GAE/100 g. ${ }^{2}$ Results expressed as mg RE/100 g. ${ }^{3}$ Results expressed as $\mu \mathrm{mol}$ Trolox/g. ${ }^{4}$ Results expressed as $\mu \mathrm{mol} \mathrm{Fe}{ }^{2+} / \mathrm{g}$.

In relation to the antioxidant capacity of the extracts of umbu fruit peel it was registered for $\mathrm{ABTS}^{\bullet+} \mathrm{DPPH}^{\bullet}$ and FRAP assays that this potential increased 12, 3.3 and 4.2 times, respectively. It corroborates those operational conditions which have great influence on antioxidant capacity, as also observed for TPC and TFC contents. Furthermore, the results corroborate that the interaction compound-radical is different, being, therefore, relevant using various assays for evaluation of the antioxidant capacity of plant samples. It is important to emphasize that antioxidant potential observed in the umbu fruit peel is due to the presence of bioactive compounds such as phenolics [13] and their recovery is an alternative to add value to fruit agro-chain, since peels are discarded after depulping.

The highest value found for ABTS ${ }^{\bullet+}$ response in our work $(109 \mu \mathrm{mol}$ Trolox/g) was close to data reported by Ribeiro et al. [3], who evaluated different fractions of umbu fruit $(143 \mu \mathrm{mol}$ Trolox $/ \mathrm{g})$. In the study performed by those authors, the fruit peel was submitted to successive extractions with 50\% methanol and 70\% acetone (analytical extraction), which improves the recovery of bioactive compounds. Thus, they have reported a higher value of antioxidant capacity. However, these solvents are toxic, which can reduce the potential for their further application, mainly in the food industry. 
Regarding statistical analysis, all models were significant for predicting the pattern of the responses in relation to independent variables, since the calculated F-values were higher than listed F-values $\left(\mathrm{F}_{9,7}=3.68\right)$ at $p=0.05$. For TPC, TFC, ABTS ${ }^{\bullet+}$, DPPH ${ }^{\bullet}$ and FRAP responses, calculated F-values were 7.74, 7.27, 16.34, 18.38 and 7.08, respectively. In addition, it is worth emphasizing that lack of fit was non-significant since it presented $p$-values lower than 0.05 and calculated F-values lower than the listed F-value for all responses. The $\mathrm{R}^{2}$ values of the fitted models were $0.91,0.90,0.95,0.96$ and 0.91 for TPC, TFC, ABTS ${ }^{\bullet+}, \mathrm{DPPH}^{\bullet}$ and FRAP responses, respectively, showing that the models explained, at least, $90 \%$ of the data variability obtained from this experimental design. Therefore, the response surfaces were constructed to relate independent variables and responses. Figures 1 and 2 show the effect of temperature and ethanol concentration, with the solid-liquid ratio fixed at 1:35, on the TPC and TFC contents and antioxidant capacity measured by $\mathrm{ABTS}^{\bullet+}, \mathrm{DPPH}^{\bullet}$ and FRAP assays. The solid-liquid ratio was fixed at 1:35 because it had lower influence on results, as can be seen in Pareto charts (Figures 1 and 2), except for antioxidant capacity by $\mathrm{DPPH}^{\bullet}$ assay.
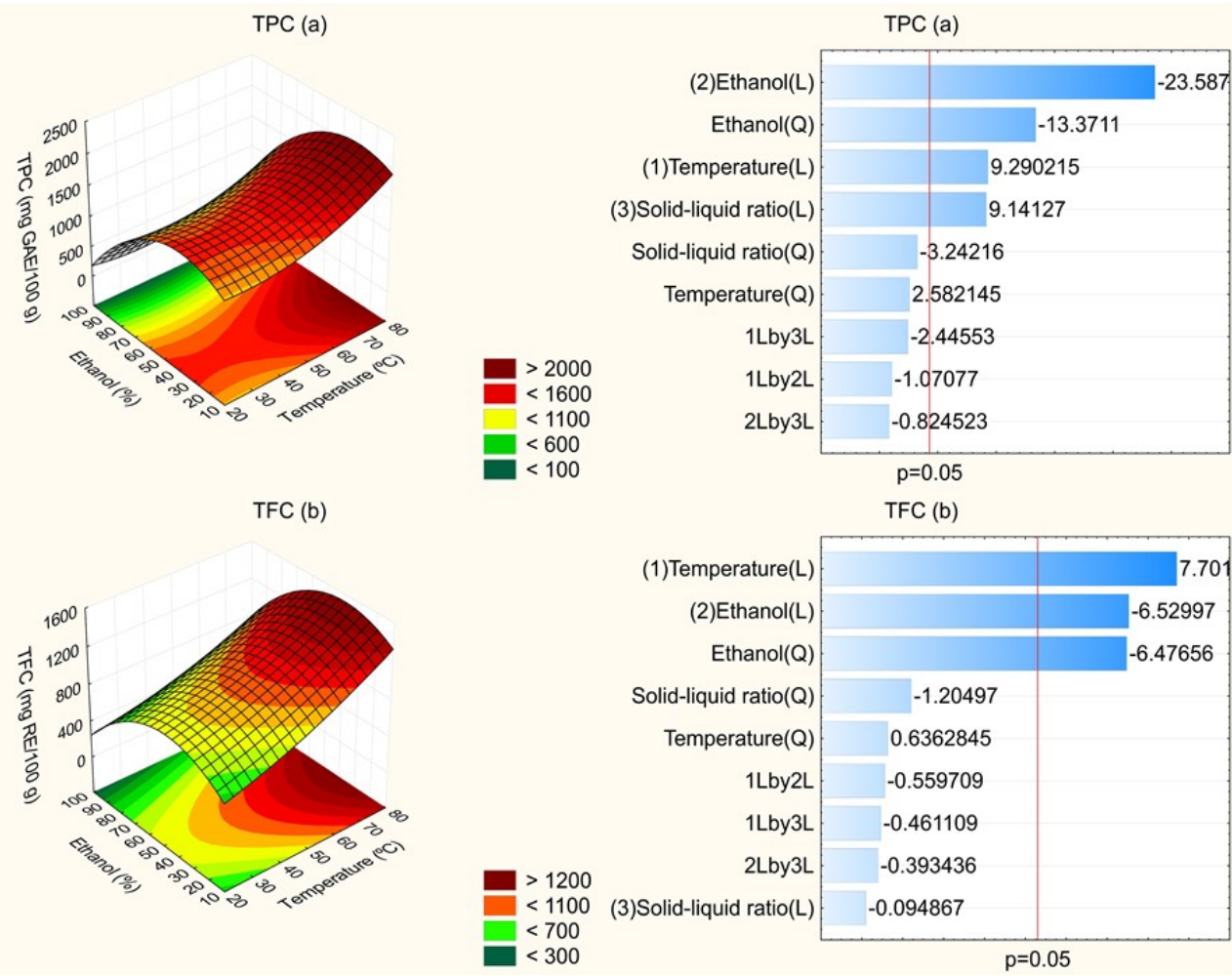

Figure 1. Effect of the independent variables on the total phenolic compounds (TPC) (a), total flavonoid compounds (TFC) (b).

By means of the Pareto Chart (Figure 1a), it is possible to note that ethanol concentration had a higher influence on the TPC content of extracts. The linear effect presented a significant and negative value at $p=0.05$. Additionally, it was observed that the quadratic effect of this factor was significant. It corroborates that there is a maximum value of ethanol concentration, which promotes higher attainment of phenolic compounds. From this value, there is lower recovery of these compounds. In addition, the linear effects of temperature and solid-liquid ratio were significant and positive. In this way, there is higher recovery of phenolic compounds from umbu fruit peel from increase in these parameters. Through response surface (Figure 1a), it is registered that using temperatures higher than $60{ }^{\circ} \mathrm{C}$ and ethanol solution between 20 and 50\%, high TPC content was obtained. 

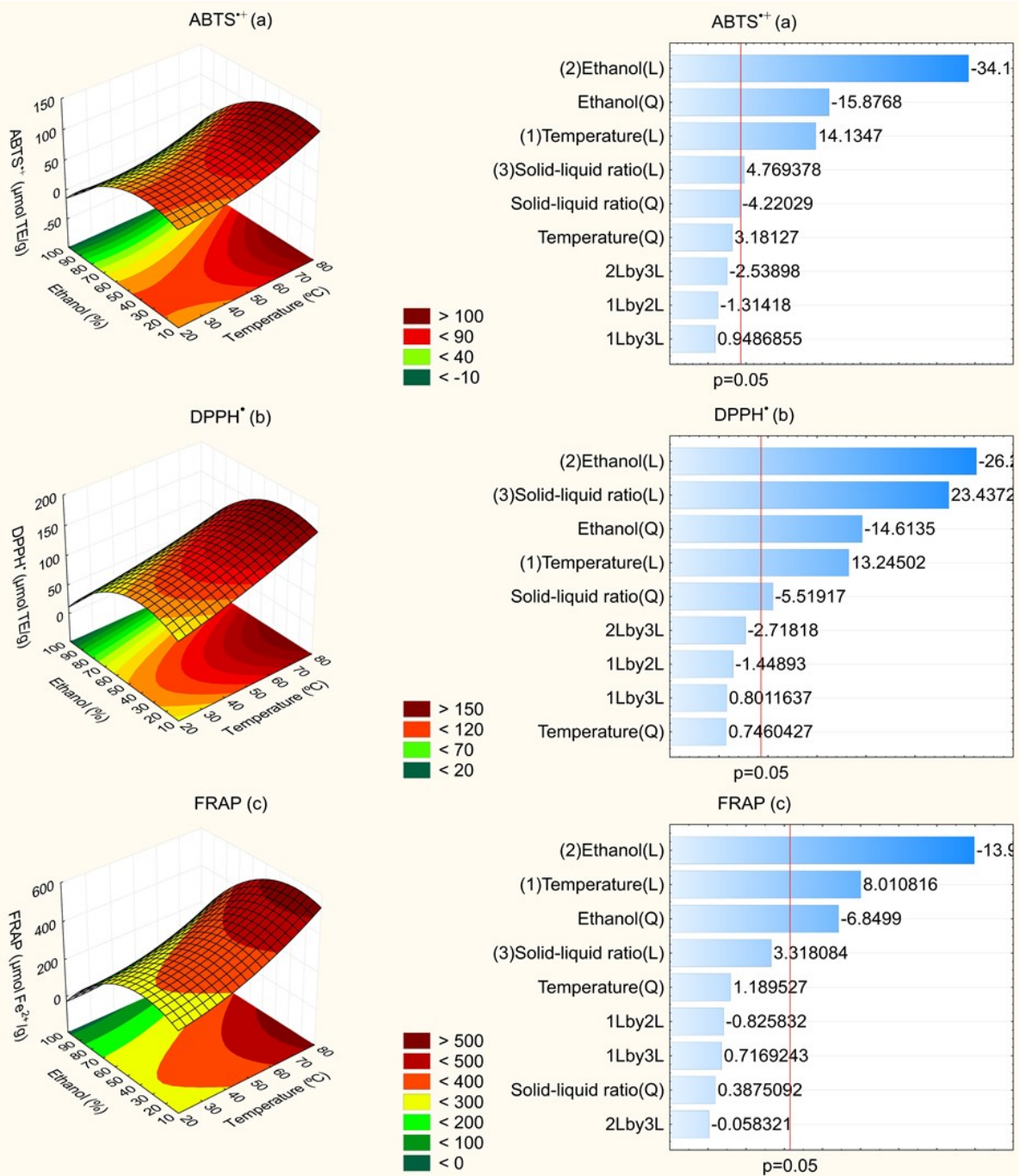

Figure 2. Effect of the independent variables on the antioxidant capacity by $\operatorname{ABTS}^{\bullet+}(\mathbf{a}), \mathrm{DPPH}^{\bullet}(\mathbf{b})$ and FRAP (c) assays.

It was observed by the TFC content that the positive and linear effect of temperature was that with a higher influence on recovery of flavonoid compounds followed by the linear and quadratic effect of ethanol concentration, which were both negative $(p<0.05)$ (Figure 1b). Thus, as it was cited above, the temperature increases the recovery of flavonoid compounds from fruit peel. For ethanol concentration, there is a limit for this pattern since that quadratic effect was also significant. From the response surface, it is possible to observe that, at zones in intense red, there was higher recovery of flavonoids of umbu fruit peel, which comprises temperature between 70 and $80^{\circ} \mathrm{C}$ and ethanol concentration between 20 and $60 \%$ (Figure $1 \mathrm{~b}$ ). However, it is important to stress that the boiling point of ethanol is $78.2^{\circ} \mathrm{C}$; therefore, it is not adequate to exceed it. Furthermore, the elevation of temperature can raise the process cost.

The antioxidant capacity by ABTS ${ }^{\bullet+}$ assay had the same behavior observed for TPC content in relation to influence of independent variables. Ethanol concentration exerted a negative effect on this response, being inversely proportional to antioxidant potential of extract, in other words, high ethanol concentrations reduced the antioxidant capacity of extracts by recovering less antioxidant compounds. Temperature above $60^{\circ} \mathrm{C}$ and ethanol concentration below $50 \%$ comprise the range in the intense red zone with higher antioxidant capacity from this assay (Figure 2a). 
By $\mathrm{DPPH}^{\bullet}$ assay, the factors with a significant influence on this response were the linear effect of ethanol concentration, the linear effect of solid-liquid ratio, the quadratic effect of ethanol concentration, the linear effect of temperature and the effect quadratic of the solid-liquid ratio. Likewise, the ethanol concentration favored recovery of antioxidant compounds (Figure 2b). Additionally, it is important to highlight that the solid-liquid ratio had a higher influence on this response, when compared to other responses evaluated in this study.

The antioxidant capacity measured by FRAP assay was dependent on ethanol concentration and extraction temperature, being observed to have a negative effect of ethanol concentration and positive effect of temperature. From the response surface, it is possible to note that this potential is higher when the temperature used in the extraction process was superior to $60^{\circ} \mathrm{C}$ and ethanol concentration was between 10 and 50\% (Figure 2c).

Therefore, the influence of ethanol concentration $(<50 \%)$ and temperature $\left(>60{ }^{\circ} \mathrm{C}\right)$ on recovery of bioactive compounds of umbu fruit peel is highlighted. The use of a binary solvent containing more water than ethanol was found to be more efficient for extraction. Ribeiro et al. [14] also reported that using 30\% ethanol in water as an extractive solution was more efficient to extract antioxidant compounds of siriguela peels (Spondias purpurea). Jesus et al. [15] published a positive effect of binary solvent on recovery of antioxidant compounds of vine pruning residues. According to those authors, mixtures of alcohols/water were more efficient in the extraction of phenolic compounds than monocomponent solvent due to the increase in membrane permeability of the plant material. Additionally, Oreopoulou et al. [16] reported that the efficiency of a solvent depends mainly on its ability to extract bioactive compounds, where ethanol is an adequate solvent to solubilize flavonoid glycosides, while water become more able dissolve phenolic acid glycosides, corroborating the use of a binary solvent system composed by ethanol and water. In addition, ethanol is a green, abundant and non-toxic solvent, which increases its use in the extraction processes.

The extraction temperature also has an important role in the extraction of bioactive compounds, since it increases both solute solubility and the diffusion coefficient of phenolic compounds as reported by Ruíz-García et al. [17], who obtained a higher content of phenolic compounds from grape skin when the extraction temperature was increased from $23{ }^{\circ} \mathrm{C}$ to $57^{\circ} \mathrm{C}$. However, it is important to emphasize that our results reveal that the positive effect of temperature was accompanied by the effect of the ethanol percentage in the extraction solution, which corroborates the optimization of extraction processes. Furthermore, as reported by Markom et al. [18], the surface tension and viscosity of the solvent are drastically reduced at boiling point when compared to at a lower temperature. In this context, the solvent can easily reach the cell wall of the plant material. Thus, the bioactiverich extract is mainly the result of the synergistic effect of the ethanol concentration in the extractive solution and the process temperature.

\subsection{Selection of the Optimal Operational Condition}

As cited above, each response presented different operational conditions for the extraction of bioactive compounds of umbu fruit peel. Thus, to better understand the results and to obtain the optimal condition of temperature, ethanol concentration and solidliquid ratio, which would improve the recovery of bioactive compounds, the simultaneous optimization method was used. Figure 3 shows individual and overall desirability profiles for the extraction conditions and evaluated responses. The overall desirability value reached was equal to 0.97 , corresponding to the optimal operational condition for extraction of bioactive compounds from fruit peel. Therefore, the extraction should be performed at $74{ }^{\circ} \mathrm{C}$, using ethanol $37 \%$, and a solid-liquid ratio of $1: 38$ in order to maximize the recovery of these compounds. 


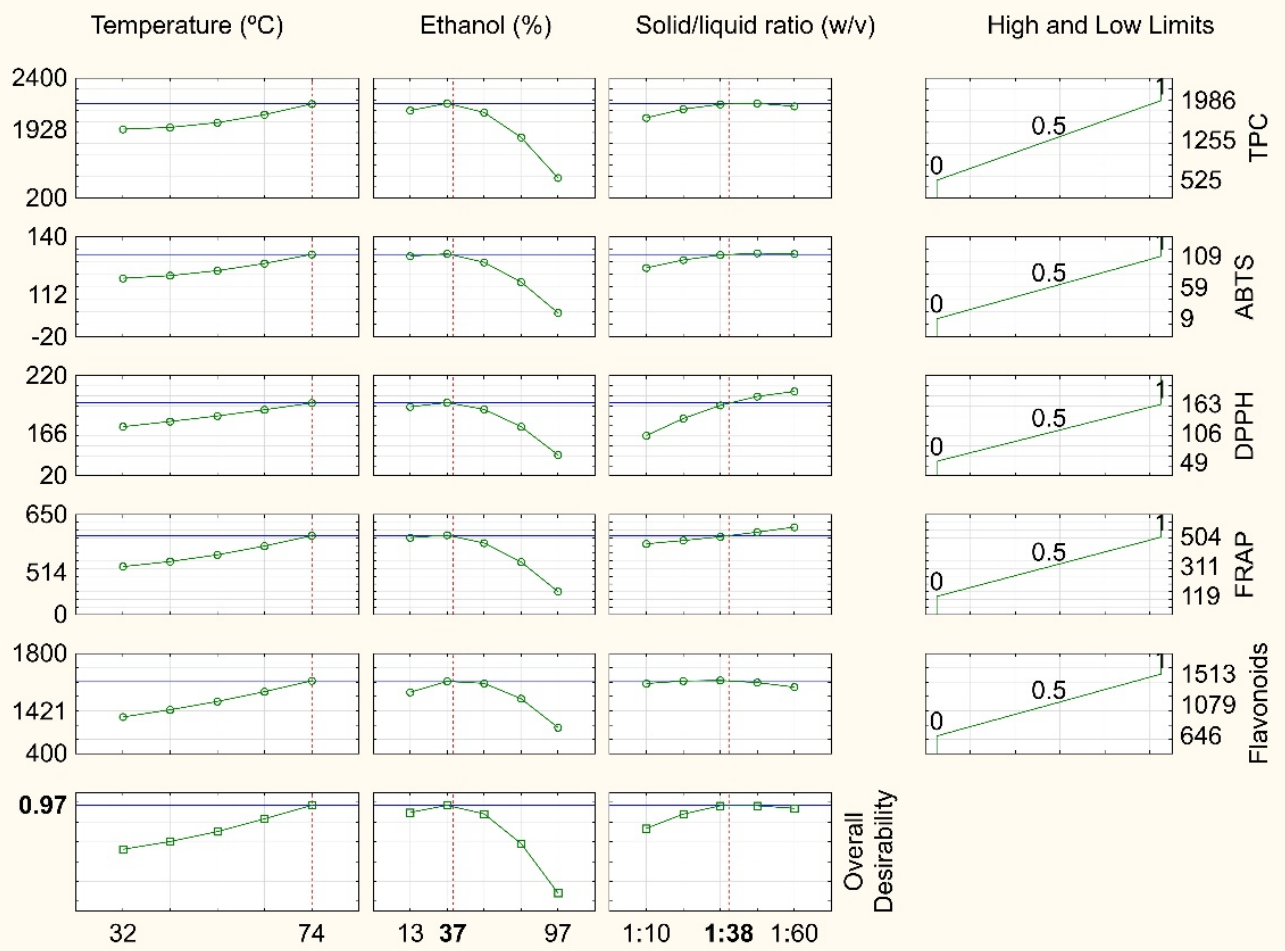

Figure 3. Profile of predicted values for individual and overall desirability for the extraction optimization. TPC — total phenolic compounds (mg GAE/100 g); TFC—-total flavonoid compounds (mg $\mathrm{RE} / 100 \mathrm{~g}) ; \mathrm{ATBS}^{\bullet+}-(\mu \mathrm{mol} \mathrm{TE} / \mathrm{g}) ; \mathrm{DPPH}^{\bullet}-(\mu \mathrm{mol} \mathrm{TE} / \mathrm{g}) ; \mathrm{FRAP}-\left(\mu \mathrm{mol} \mathrm{Fe} e^{2+} / \mathrm{g}\right)$.

In this operational condition, observed values of TPC (1985 mg GAE/100 g); TFC (1364 mg RE/100 g); and antioxidant capacity by $\mathrm{ABTS}^{\bullet+}(122 \mu \mathrm{mol} \mathrm{TE} / \mathrm{g}), \mathrm{DPPH}^{\bullet}$ $(174 \mu \mathrm{mol} / \mathrm{TE} \mathrm{g})$, and FRAP assays $\left(468 \mu \mathrm{mol} \mathrm{Fe}{ }^{2+} / \mathrm{g}\right)$ were close to the predicted values by the experimental design as follows: TPC (1928 mg GAE/100 g); TFC (1421 mg $\mathrm{RE} / 100 \mathrm{~g})$; antioxidant capacity by $\mathrm{ABTS}^{\bullet+}(112 \mu \mathrm{mol} \mathrm{TE} / \mathrm{g}), \mathrm{DPPH}^{\bullet}(166 \mu \mathrm{mol} \mathrm{TE} / \mathrm{g})$, and FRAP assays $\left(514 \mu \mathrm{mol} \mathrm{Fe} \mathrm{F}^{2+} / \mathrm{g}\right)$ with coefficients of variation less than $7 \%$. Therefore, the results showed that the experimental design is adequate to obtain the optimal operational condition for extraction of bioactive compounds of umbu fruit peel.

\subsection{Bioactive Profile by LC-HRMS}

LC-HRMS analysis allowed the identification of 15 different chemical compounds in the extract (Tables 2 and 3). In accordance with experimental section, identification was performed by MS/MS fragmentation pattern, comparison with the GNPS library and selection of those hits that were previously isolated from Spondias spp. $[3,19,20]$, compounds from species belonging to the Anacardiaceae family or compounds common in plant species (see Tables 2 and 3). It was not possible to construct clusters due to the relatively low fragmentation pattern of the sample. Compounds were better ionized in positive mode. Pipecolic acid and anthranilic acid and their derivatives were proposed since they are very common plant secondary metabolites, including in fruits [21,22]. The annotation of compounds 2'-hydroxy-4'-methoxyacetophenone, 4-acetyl-2-prenylphenol, and rubinaphthin A was based on phenolic compounds that can be found in many plant species, as well as phenolic acids that have already been identified in Spondias spp., such as gallic acid, 3,5-dihydroxybenzoic acid, and coumaric acid [3,19,20]. That noted, flavonoids, benzoic acid derivatives, glycosides (koaburside), $\mathrm{C}_{6}-\mathrm{C}_{3}$ derivatives, among other compounds, were identified in the extract. Some attention should be paid to rutin, which was identified in both ionization modes. This compound was previously identified in umbu fruit and has shown many biological properties such as cardiovascular, anticancer, anti-inflammatory, antidiabetic, anti-obesity, antimicrobial, anti-leishmanial, antioxidant 
activities and others $[3,19,20,23]$. It is already known that flavonoids and phenolic acids have great antioxidant properties, as shown in our work [24,25].

Table 2. Metabolites tentatively identified by LC-HRMS in negative ion mode.

\begin{tabular}{|c|c|c|c|c|c|c|c|}
\hline$\#$ & $t_{\mathrm{R}}(\min )$ & $\begin{array}{c}m / z \\
\text { Observed }\end{array}$ & $\begin{array}{c}m / z \\
\text { Theoretical }\end{array}$ & $\begin{array}{l}\text { Molecular } \\
\text { Formula }\end{array}$ & $\begin{array}{l}\text { Fragment } \\
\text { Ions }(m / z)\end{array}$ & Metabolite & Organism/Reference \\
\hline 1 & 4.14 & 153.0200 & 153.0193 & $\mathrm{C}_{7} \mathrm{H}_{6} \mathrm{O}_{4}$ & $\begin{array}{l}125.0261 \\
109.0279\end{array}$ & $\begin{array}{c}3,5- \\
\text { Dihydroxybenzoic } \\
\text { acid }\end{array}$ & $\begin{array}{l}\text { Already described in } \\
\text { Spondias spp. [19] }\end{array}$ \\
\hline 2 & 18.45 & 609.1482 & 609.1461 & $\mathrm{C}_{27} \mathrm{H}_{30} \mathrm{O}_{16}$ & $\begin{array}{l}301.0357 ; \\
300.0288 ; \\
273.0350 ; \\
257.0430 ; \\
151.0033\end{array}$ & Rutin & $\begin{array}{l}\text { Already described in } \\
\text { Spondias spp. }[3,20]\end{array}$ \\
\hline 3 & 18.72 & 463.0862 & 463.0882 & $\mathrm{C}_{21} \mathrm{H}_{20} \mathrm{O}_{12}$ & $\begin{array}{l}300.0256 \\
271.0236 \\
255.0342\end{array}$ & Isoquercitrin & $\begin{array}{l}\text { Already described in } \\
\text { Spondias spp. [19] }\end{array}$ \\
\hline 4 & 20.62 & 593.1535 & 593.1512 & $\mathrm{C}_{27} \mathrm{H}_{30} \mathrm{O}_{15}$ & $\begin{array}{l}285.0372 ; \\
284.0343 ; \\
257.0501 ; \\
255.0366 ; \\
227.0402\end{array}$ & $\begin{array}{l}\text { Kaempferol } \\
\text { 3-O-rutinoside }\end{array}$ & $\begin{array}{l}\text { Already described in } \\
\text { Spondias spp. [19] }\end{array}$ \\
\hline 5 & 35.27 & 193.0709 & 193.0506 & $\mathrm{C}_{10} \mathrm{H}_{10} \mathrm{O}_{4}$ & $\begin{array}{l}178.0512 ; \\
149.0979 ; \\
134.0676\end{array}$ & Ferulic acid & $\begin{array}{l}\text { Already described in } \\
\text { Spondias spp. [19] }\end{array}$ \\
\hline
\end{tabular}

Table 3. Metabolites tentatively identified by LC-HRMS in positive ion mode.

\begin{tabular}{|c|c|c|c|c|c|c|c|c|}
\hline \# & $t_{\mathrm{R}}(\min )$ & $\begin{array}{c}m / z \\
\text { Observed }\end{array}$ & $\begin{array}{c}m / z \\
\text { Theoretical }\end{array}$ & $\begin{array}{l}\text { Molecular } \\
\text { Formula }\end{array}$ & Adduct & $\begin{array}{l}\text { Fragment } \\
\text { Ions }(m / z)\end{array}$ & Metabolite & Organism/Reference \\
\hline 6 & 1.58 & 325.1329 & 325.1129 & $\mathrm{C}_{12} \mathrm{H}_{22} \mathrm{O}_{11}$ & {$\left[\mathrm{M}-\mathrm{H}_{2} \mathrm{O}+\mathrm{H}\right]^{+}$} & $\begin{array}{c}145.0502 ; \\
127.0399 ; \\
85.0297 ; \\
69.0342 ; \\
55.0188\end{array}$ & Sucrose & Very common in plants \\
\hline 7 & 3.10 & 130.0863 & 130.0863 & $\mathrm{C}_{6} \mathrm{H}_{11} \mathrm{NO}_{2}$ & {$[\mathrm{M}+\mathrm{H}]^{+}$} & $\begin{array}{l}84.0427 ; \\
57.0692 ; \\
56.0506\end{array}$ & Pipecolic acid & Found in Citrus spp. [21] \\
\hline 8 & 7.47 & 165.0545 & 165.0546 & $\mathrm{C}_{9} \mathrm{H}_{8} \mathrm{O}_{3}$ & {$[\mathrm{M}+\mathrm{H}]^{+}$} & $\begin{array}{l}147.0445 ; \\
120.0824 ; \\
119.0515\end{array}$ & Coumaric acid & $\begin{array}{l}\text { Already described in } \\
\text { Spondias spp. }[3,20]\end{array}$ \\
\hline 9 & 7.82 & 347.1670 & 347.1337 & $\mathrm{C}_{15} \mathrm{H}_{22} \mathrm{O}_{9}$ & {$[\mathrm{M}+\mathrm{H}]^{+}$} & $\begin{array}{l}185.0790 \\
154.0640 \\
153.0560 \\
125.0600\end{array}$ & $\begin{array}{c}3,4,5- \\
\text { Trimethoxyphenyl } \\
\text { beta-D- } \\
\text { glucopyranoside } \\
\text { (Koaburside) }\end{array}$ & $\begin{array}{c}\text { Found in Rhus parviflora } \\
\text { (Anacardiaceae) [26] } \\
\text { Found in } \\
\text { Cladogynos orientalis } \\
\text { (Euphorbiaceae) [27] }\end{array}$ \\
\hline 10 & 9.62 & 138.0557 & 138.0550 & $\mathrm{C}_{7} \mathrm{H}_{7} \mathrm{NO}_{2}$ & {$[\mathrm{M}+\mathrm{H}]^{+}$} & $\begin{array}{c}121.0657 \\
92.9800 ; \\
65.0410\end{array}$ & Anthranilic acid & $\begin{array}{l}\text { Found in Arabidopsis } \\
\text { thaliana (Cruciferae) [28] }\end{array}$ \\
\hline 2 & 18.40 & 611.1614 & 611.1607 & $\mathrm{C}_{27} \mathrm{H}_{30} \mathrm{O}_{16}$ & {$[\mathrm{M}+\mathrm{H}]^{+}$} & $\begin{array}{l}465.1022 ; \\
303.0496 ; \\
145.0511 ; \\
129.0568\end{array}$ & Rutin & $\begin{array}{l}\text { Already described in } \\
\text { Spondias spp. }[3,20]\end{array}$ \\
\hline
\end{tabular}


Table 3. Cont.

\begin{tabular}{|c|c|c|c|c|c|c|c|c|}
\hline \# & $t_{\mathrm{R}}(\min )$ & $\begin{array}{c}m / z \\
\text { Observed }\end{array}$ & $\begin{array}{c}m / z \\
\text { Theoretical }\end{array}$ & $\begin{array}{l}\text { Molecular } \\
\text { Formula }\end{array}$ & Adduct & $\begin{array}{l}\text { Fragment } \\
\text { Ions }(m / z)\end{array}$ & Metabolite & Organism/Reference \\
\hline 3 & 18.54 & 465.1028 & 465.1028 & $\mathrm{C}_{21} \mathrm{H}_{20} \mathrm{O}_{12}$ & {$[\mathrm{M}+\mathrm{H}]^{+}$} & $\begin{array}{l}447.1002 \\
303.0463 \\
258.0178 \\
231.1018\end{array}$ & Isoquercitrin & $\begin{array}{l}\text { Already described in } \\
\text { Spondias spp. [19] }\end{array}$ \\
\hline 11 & 19.42 & 167.0705 & 167.0703 & $\mathrm{C}_{9} \mathrm{H}_{10} \mathrm{O}_{3}$ & {$[\mathrm{M}+\mathrm{H}]^{+}$} & $\begin{array}{l}149.0260 ; \\
125.0960 ; \\
121.0310\end{array}$ & $\begin{array}{c}\text { 2'-Hydroxy-4'- } \\
\text { methoxyacetophenone } \\
\text { (Paeonol) }\end{array}$ & $\begin{array}{l}\text { found in Paeonia spp. } \\
\text { (Ranunculaceae) [29] }\end{array}$ \\
\hline 12 & 36.01 & 205.1166 & 205.1223 & $\mathrm{C}_{13} \mathrm{H}_{16} \mathrm{O}_{2}$ & {$[\mathrm{M}+\mathrm{H}]^{+}$} & $\begin{array}{c}149.0255 ; \\
121.0309 ; \\
107.0825 ; \\
59.0501\end{array}$ & $\begin{array}{l}\text { 4-Acetyl-2- } \\
\text { prenylphenol }\end{array}$ & $\begin{array}{c}\text { Found in Polymnia } \\
\text { sonchifolia } \\
\text { (Asteraceae) [30] }\end{array}$ \\
\hline 13 & 36.11 & 581.1551 & 581.1501 & $\mathrm{C}_{26} \mathrm{H}_{28} \mathrm{O}_{15}$ & {$[\mathrm{M}+\mathrm{H}]^{+}$} & $\begin{array}{l}303.1460 \\
302.1490 \\
153.0967 \\
149.0236\end{array}$ & $\begin{array}{l}\text { Quercetin- } \\
\text { deoxyhexosyl- } \\
\text { pentoside }\end{array}$ & Very common in plants \\
\hline 14 & 38.09 & 389.2336 & 389.0843 & $\mathrm{C}_{17} \mathrm{H}_{18} \mathrm{O}_{9}$ & {$[\mathrm{M}+\mathrm{Na}]^{+}$} & $\begin{array}{l}149.0240 \\
147.0656 \\
129.0550 \\
71.0850 \\
57.0705\end{array}$ & Rubinaphthin A & $\begin{array}{c}\text { Found in Rubia spp. } \\
\text { (Rubiaceae), i.e., Rubia } \\
\text { yunnanensis [31] }\end{array}$ \\
\hline 15 & 42.19 & 197.0812 & 197.0808 & $\mathrm{C}_{10} \mathrm{H}_{12} \mathrm{O}_{4}$ & {$[\mathrm{M}+\mathrm{H}]^{+}$} & $\begin{array}{l}179.0861 ; \\
169.0027 ; \\
137.0633 ; \\
95.0850\end{array}$ & Dihydroferulic acid & Very common in plants \\
\hline
\end{tabular}

\subsection{Antimicrobial Assays}

The antimicrobial action of the optimized extract from umbu fruit peel was tested against a variety of both Gram-positive and Gram-negative bacteria as well as against Candida species (Table 4). The results showed a distinct ability of the umbu fruit peel extract to inhibit the microbial viability with more action on Gram-positive bacteria (MIC values varying from 0.03 to $0.06 \mathrm{mg}$ GAE $/ \mathrm{mL}$ ) compared to Gram-negative (MIC $=0.12 \mathrm{mg}$ $\mathrm{GAE} / \mathrm{mL}$ ), while it was completely ineffective against Candida species, which reveals its ability to act against bacteria, but not against fungi. The minimum bactericidal concentration ranged from 0.06 to $0.24 \mathrm{mg}$ GAE/mL, making the Gram-positive more susceptible than Gram-negative bacteria. These results can be explained, at least in part, due to the morphological differences observed between these two groups, in which Gram-negative bacteria have an extra outer membrane together with periplasmic space that serves as a selective permeation barrier, thus reducing chemical interaction and inhibition effects of extract [32]. Various studies have attributed the inhibitory effect of plant extracts against different bacteria to their phenolic compounds, such as those tentatively identified in the present work by LC-HRMS (Tables 2 and 3). These compounds can present the ability to bind with the bacterial cell wall and then inhibit the bacterial growth. Additionally, phenolic compounds may precipitate protein and inhibit enzymes of microorganisms [33]. Moreover, it is relevant to stress that antibacterial action may be due to the synergy of several compounds, including phenolic acids and flavonoid derivatives and other bioactive compounds presented in Tables 2 and 3.

\section{5. $\alpha$-Amylase Inhibition}

In this set of experiments, the effect of extract from umbu fruit peel on $\alpha$-amylase activity was evaluated. The results revealed that umbu extract inhibited the $\alpha$-amylase activity in a typically dose-dependent way. In this context, the extract at a concentration of $0.01 \mathrm{mg} \mathrm{GAE} / \mathrm{mL}$ showed a percentage of inhibition of $38.3 \%$ and at $0.273 \mathrm{mg} \mathrm{GAE} / \mathrm{mL}$ it was increased to $87.4 \%$. The extract presented an $\mathrm{IC}_{50}$ value of $0.076 \mathrm{mg} \mathrm{GAE} / \mathrm{mL}$. The acarbose is widely used in medicine as an inhibitor of digestive enzymes related to 
the breakout of polysaccharides. As these enzymes are inhibited, there is reduction in the absorption of glucose, and consequently the reduction of postprandial blood glucose level elevation, which helps to reduce risk of Diabetes Mellitus and other diseases [34,35]. The $\mathrm{IC}_{50}$ value of the standard drug was found to be $0.034 \mathrm{mg} / \mathrm{mL}$. Even though a lower concentration of this medicine is required for inhibition at $50 \% \alpha$-amylase activity when compared to the umbu fruit extract, it is highlighted that this extract, obtained from residue of umbu fruit depulp, presented good inhibitory activity against $\alpha$-amylase when compared to literature data. Laaroussi et al. [36] reported that different propolis samples from Morocco presented $\mathrm{IC}_{50}$ values between 0.195 and $0.964 \mathrm{mg} / \mathrm{mL}$, being, therefore, higher than that found in umbu fruit extract. This comparison is interesting, because the phytochemical composition of propolis samples indicated the presence of phenolic acids, flavonoids and stilbenes, which is similar to umbu fruit extract composition. Thus, these results indicate that umbu fruit extract is a promising candidate for control and prevention of Diabetes type 2 .

Table 4. Antimicrobial activity of umbu fruit peel extract.

\begin{tabular}{lcc}
\hline \multirow{2}{*}{\multicolumn{1}{c}{ Microorganisms }} & \multicolumn{2}{c}{ Antimicrobial Assays (mg GAE/mL) ${ }^{1}$} \\
\cline { 2 - 3 } & \multicolumn{1}{c}{ MIC Values } & MBC/MFC Values \\
\hline Gram-positive bacteria & & \\
Bacillus subtilis 168 LMD 74.6 & 0.06 & 0.12 \\
Staphylococcus aureus ATCC 29213 & 0.06 & 0.06 \\
Staphylococcus epidermidis ATCC 12228 & 0.03 & 0.12 \\
Gram-negative bacteria & & \\
Escherichia coli ATCC 25922 & 0.12 & 0.24 \\
Acinetobacter baumannii ATCC 19606 & 0.12 & 0.24 \\
Psedomonas aeruginosa ATCC 27853 & 0.12 & 0.24 \\
Klebsiella pneumoniae ATCC13883 & 0.12 & 0.24 \\
Fungi & & \\
Candida albicans ATCC 90028 & ND & ND \\
Candida tropicalis ATCC 750 & ND & ND \\
\hline
\end{tabular}

ND—not detected. ${ }^{1}$ Results expressed as mg gallic acid equivalent $/ \mathrm{mL}$. MIC—-minimum inhibitory concentration. $\mathrm{MBC}$ - minimum bactericidal concentration. MFC—-minimum fungicidal concentration.

\section{Materials and Methods}

\subsection{Umbu Fruit Peel}

For this work, ripe umbu fruits $(2.4 \mathrm{~kg})$ purchased on the local market of Rio de Janeiro were used. For that, they were sanitized using sodium hypochlorite (100 ppm) and manually depulped using a domestic sieve. Then, umbu peels were dried in an oven with forced air circulation at $45{ }^{\circ} \mathrm{C}$ for $45 \mathrm{~h}$. The dried peels were disintegrated in a domestic mixer to obtain a powder. It was presented with moisture equal to $17 \%(w / w)$, gravimetrically determined at $105^{\circ} \mathrm{C}$.

\subsection{Thermal-Assisted Solid-Liquid Extraction}

The extraction of bioactive compounds was performed by agitated solvent extraction, using $125 \mathrm{~mL}$ glass flasks duly covered and heated for $60 \mathrm{~min}$ under constant stirring of $130 \mathrm{rpm}$. These variables were fixed according to Ribeiro et al. [14], who obtained antioxidant compound-rich extract from siriguela peels. The work temperature was selected taking into account the boiling point of ethanol in order to avoid loss during the extraction process. The extraction temperature, ethanol percentage and solid-liquid ratio $(w / v)$ were ranged aiming to evaluate their effect on responses. The variation interval of the independent variables was selected based on preliminary data and works published by our laboratory $[14,37]$. Obtained extracts were filtered in quantitative filter paper (FP41, Quanty) and stored in the freezer until further analysis. 


\subsection{Experimental Design}

The effect of the independent variables (extraction temperature, ethanol percentage in the extractive solution and solid-liquid ratio) on the content of total phenolic compounds (TPC) and total flavonoid compounds (TFC) and antioxidant capacity by $\mathrm{ABTS}^{\bullet+}, \mathrm{DPPH}^{\bullet}$ and FRAP assays were evaluated using the response surface methodology (RSM) based on rotational central composite design, composed of 8 factorial points (level \pm 1 ), 3 central points (level 0 ) and 6 axial points (level \pm 1.68 ), resulting in 17 trials. Table 1 shows the combination of the independent variables (coded and real values). The experimental data were analyzed by RSM, using the second order polynomial equation. Analysis of variance (ANOVA), test for the lack of fit and coefficient of determination $\left(R^{2}\right)$ were used to verify model significance.

To determine the optimal condition for extraction of the bioactive compounds of umbu fruit peel, the technique of simultaneous optimization of independent variables (desirability) was used. The desirability function is based on the conversion of each response in an individual desirability (d). After that, they are combined into an overall desirability $(D)$, using the geometric mean. The $D$ value ranges from zero (0) to one (1), in which the value of 1 corresponds to the desirable response [38]. Under the optimal operational condition, more assays were performed and observed results were compared with those predicted by the model.

\subsection{Chemical Analysis}

\subsubsection{Total Phenolic Compounds (TPC)}

This determination was performed using the Folin-Ciocalteu reagent (Imbralab, Ribeirão Preto, Brazil) according to the method described by Georgé et al. [39]. For the reactions, $250 \mu \mathrm{L}$ of each filtered and properly diluted extract were mixed with $1250 \mu \mathrm{L}$ of $10 \%(v / v)$ Folin-Ciocalteu reagent and $1000 \mu \mathrm{L}$ of $7.5 \%(w / v) \mathrm{Na}_{2} \mathrm{CO}_{3}$ solution. Thereafter, samples were heated at $50{ }^{\circ} \mathrm{C}$ for $15 \mathrm{~min}$ and cooled at room temperature using an ice bath. The absorbance was measured at $760 \mathrm{~nm}$. A calibration curve was created from a gallic acid standard, which ranged from 10 to $100 \mathrm{mg} / \mathrm{L}$. TPC content was expressed as $\mathrm{mg}$ gallic acid equivalent per $100 \mathrm{~g}$ (mg GAE 100/g).

\subsubsection{Total Flavonoid Compounds (TFC)}

The TFC content was determined based on the method described by Zhishen et al. [40] with minor modifications. Here, $0.5 \mathrm{~mL}$ of extract was mixed with $3.2 \mathrm{~mL}$ of ultrapure water and $150 \mu \mathrm{L}$ of $\mathrm{NaNO}_{2}(5 \%)$. After homogenization, the mixture was left to stand for $5 \mathrm{~min}$. Thereafter, $150 \mu \mathrm{L}$ of $\mathrm{AlCl}_{3}(10 \%)$ was added to the mixture, and $1 \mathrm{~mL}$ of $\mathrm{NaOH}(1 \mathrm{M})$ was added after one minute. The absorbance was recorded at $510 \mathrm{~nm}$ with a spectrophotometer (Metash, Shanghai, China) using ultrapure water as a blank. The TFC content was calculated using the calibration curve of rutin, with concentration ranging from 99 to $595 \mathrm{mg} / \mathrm{L}$. The results were expressed as $\mathrm{mg}$ rutin equivalents per $100 \mathrm{~g}$ (RE/100 g).

\subsubsection{ABTS $^{\bullet+}$ Assay}

The antioxidant capacity was determined by the reduction method of the ABTS ${ }^{\bullet+}$ radical (Sigma-Aldrich, Saint Louis, MO, USA) according to Gião et al. [41]. For the reactions, $30 \mu \mathrm{L}$ of each filtered and duly diluted extract were mixed with $3000 \mu \mathrm{L}$ ABTS ${ }^{\bullet+}$ radical. After $6 \mathrm{~min}$, the absorbance was measured at $734 \mathrm{~nm}$ with a spectrophotometer in spectrophotometric units (Metash, Shanghai, China) using ultra-pure water as a blank. The ABTS $^{\bullet+}$ antiradical activity was calculated using Trolox solutions (Sigma-Aldrich, Buchs, Switzerland) with different concentrations in a range of 500-2000 $\mu \mathrm{mol}$. Results were expressed as $\mu \mathrm{mol}$ Trolox equivalents per gram $(\mu \mathrm{mol} \mathrm{TE} / \mathrm{g})$.

\subsection{4. $\mathrm{DPPH}^{\bullet}$ Assay}

The $\mathrm{DPPH}^{\bullet}$ radical (Sigma-Aldrich, Steinheim, Germany) scavenging activity of extracts was determined according to the method described by Hidalgo, Sánchez-Moreno 
and Pascual-Teresa [42]. For the reactions, $100 \mu \mathrm{L}$ of each duly diluted extract was added to $2900 \mu \mathrm{L}$ of $\mathrm{DPPH}^{\bullet}$ solution $\left(6 \times 10^{-5} \mathrm{M}\right.$ in methanol and diluted to an absorbance of 0.700 at $517 \mathrm{~nm}$ ). The resulting solutions were allowed to stand for $30 \mathrm{~min}$ in darkness at room temperature. After that, the absorbance was measured at $517 \mathrm{~nm}$ with a spectrophotometer (Metash, Shanghai, China) using methanol as blank. The $\mathrm{DPPH}^{\bullet}$ radical scavenging activity was calculated using Trolox solutions with different concentrations in a range of 80-700 $\mu \mathrm{mol}$. Results were expressed as $\mu \mathrm{mol}$ Trolox (Sigma-Aldrich, Buchs, Switzerland) equivalents per gram ( $\mu \mathrm{mol} \mathrm{TE} / \mathrm{g})$.

\subsubsection{FRAP Assay}

This assay was performed according to Benzie and Strain [43] with slight modifications. Stock solutions included $300 \mathrm{mM}$ of acetate buffer (pH 3.6), $10 \mathrm{mM}$ TPTZ (Sigma-Aldrich, Buchs, Switzerland) in $40 \mathrm{mM} \mathrm{HCl}$ and $20 \mathrm{mM} \mathrm{FeCl} \cdot 6 \mathrm{H}_{2} \mathrm{O}$. The work solution was prepared by mixing $25 \mathrm{~mL}$ of the acetate buffer, $2.5 \mathrm{~mL}$ of TPTZ solution and $2.5 \mathrm{~mL}$ of $\mathrm{FeCl}_{3} \cdot 6 \mathrm{H}_{2} \mathrm{O} .100 \mu \mathrm{L}$ of each extract was reacted with $3 \mathrm{~mL}$ of FRAP at $37^{\circ} \mathrm{C}$ for $30 \mathrm{~min}$. The absorbance was measured at $593 \mathrm{~nm}$. The ferric reducing ability power was calculated using $\mathrm{FeSO}_{4} \cdot 7 \mathrm{H}_{2} \mathrm{O}$ solutions with different concentrations in a range of 150-1200 $\mu \mathrm{mol}$. The results were expressed as $\mu \mathrm{mol} \mathrm{Fe} \mathrm{F}^{2+} / \mathrm{g}$.

\subsubsection{UPLC-qTOF/MS Analysis}

Sample extract was dissolved in an aqueous solution of formic acid $(0.1 \%, v / v)$ and subjected to Ultra-performance liquid chromatography coupled to quadrupole/time-offlight mass spectrometry (UPLC-qTOF/MS) system from Bruker Daltonics (MaxisImpact, QTOf Bruker, Bremen, Germany). The sample separation was conducted on a Hypersil C18 column ( $3 \mu \mathrm{m}$ particle size, $2.1 \mathrm{~mm}$ i.d. $\times 150 \mathrm{~mm}$ ). The column temperature was maintained at $40^{\circ} \mathrm{C}$. An aliquot of $20 \mu \mathrm{L}$ of the extract solution at $100 \mathrm{ppm}$ was injected on equipment under flow rate of $0.27 \mathrm{~mL} / \mathrm{min}$. Linear gradient elution of $\mathrm{A}(0.1 \%$ formic acid in water) and B (acetonitrile) was applied with the following gradient: $5 \% \mathrm{~B}$, and then linearly increased to $9 \%$ B within $5 \mathrm{~min}$, then $9 \%$ B was increased to $16 \%$ within $10 \mathrm{~min}$, $16 \% \mathrm{~B}$ increased to $36 \% \mathrm{~B}$ within $18 \mathrm{~min}$, and $36 \% \mathrm{~B}$ increased to $95 \% \mathrm{~B}$ within $1 \mathrm{~min}$, then holding in this concentration for $12 \mathrm{~min}$. Next, 95\% B was decreased to 5\% B within $1 \mathrm{~min}$, and finally held in this way for 13 min. Data Analysis (Bruker Daltonics, Bremen, Germany) was used for data interpretation. The mass spectra (MS) were acquired in both negative and positive modes with an electrospray ionization source (ESI). The data were scanned for each test sample from 50 to $1200 \mathrm{~m} / z$. Highly purified nitrogen $\left(\mathrm{N}_{2}\right)$ was used as the nebulizing gas and ultra-high pure helium (He) as the collision gas. In terms of negative electrospray mode, the capillary voltage was set at $5000 \mathrm{~V}$. ESI parameters applied were: dry gas: $200{ }^{\circ} \mathrm{C}$; dry gas flow: $8 \mathrm{~L} / \mathrm{min}$; nebuliser: 2 bar. The acquired data were converted to $\mathrm{mzML}$ format using MSConvert software (http:/ / proteowizard.sourceforge.net/ (accessed on 10 December 2021)) and submitted to Global Natural Products Social Molecular Network (GNPS [44]; http:/ / gnps.ucsd.edu (accessed on 10 December 2021)) online system. The molecular network calculations and database matching were constructed using $2.0 \mathrm{Da}$ as precursor ion mass tolerance and $0.05 \mathrm{Da}$ as fragment ion mass tolerance, 0.7 as minimum cosine score and 3 as minimum matched fragment ions for edge linkage. Finally, GNPS data were then imported and visualized using the Cystoscope software (version 3.8.0) to find the subnetworks portions.

\subsection{In Vitro Biological Studies}

Microorganisms and culture conditions Gram-negative (Acinetobacter baumannii ATCC 19606, Escherichia coli ATCC 25922, Klebsiella pneumoniae ATCC 13883, and Pseudomonas aeruginosa ATCC 27853) and Gram-positive (Staphylococcus aureus ATCC 29213, Staphylococcus epidermidis ATCC 12228 and Bacillus subtilis 168 LMD 74.6) bacteria were grown in Mueller-Hinton agar (Difco, Franklin Lakes, NJ, USA) for $24 \mathrm{~h}$ at $35 \pm 2{ }^{\circ} \mathrm{C}$. The yeasts 
Candida albicans ATCC 90028 and Candida tropicalis ATCC 750 were cultured in Sabouraud dextrose agar (Difco, Franklin Lakes, NJ, USA) for $24 \mathrm{~h}$ at $35 \pm 2{ }^{\circ} \mathrm{C}$.

\subsubsection{Antimicrobial Assays}

For these assays, the optimized extract was evaporated in a rotavapor under reduced pressure to eliminate ethanol. After that, the concentrated optimized extract presented TPC content equal to $0.965 \mathrm{mg} \mathrm{GAE} / \mathrm{mL}$. Antimicrobial activity was evaluated using the broth microdilution method in 96-well polystyrene plates, standardized according to document M07-A9 (for bacterial assays) and M27-A3 (for fungal assays). The minimum inhibitory concentration (MIC) was determined by visual inspection after incubation at $37^{\circ} \mathrm{C}$ for $24 \mathrm{~h}$ of extracts at final concentrations of $0.03,0.06,0.12$ and $0.24 \mathrm{mg} \mathrm{GAE} / \mathrm{mL}$. To determine the minimum bactericidal and fungicidal concentration (MBC and MFC), $10 \mu \mathrm{L}$ of the wells that had no visible microbial growth were inoculated in Mueller-Hinton culture medium and Sabouraud Dextrose Agar for $24 \mathrm{~h}$ at $37^{\circ} \mathrm{C}$. The MBC and MFC were considered to be the lowest concentration capable of completely inhibiting microbial growth on the agar surface.

\subsubsection{Assay for $\alpha$-Amylase Inhibition}

The inhibition assay for $\alpha$-amylase was performed as reported by Meng et al. [45] with minor modifications. Briefly, $100 \mu \mathrm{L}$ of extract evaporated in a rotavapor under reduced pressure to eliminate ethanol at different dilutions, was mixed with $\alpha$-amylase solution $(100 \mu \mathrm{L}, 1.0 \mathrm{U} / \mathrm{mL})$ (Sigma-Aldrich, St. Louis, MO, USA) in phosphate buffer (pH 6.9) and $250 \mu \mathrm{L}$ of $1 \%$ starch solution. The incubation was carried out for $5 \mathrm{~min}$ at $37^{\circ} \mathrm{C}$. The enzyme reaction was stopped by adding dinitrosalicylic acid reagent (Sigma-Aldrich, Steinheim, Germany) $(250 \mu \mathrm{L})$ and incubation was carried out for $15 \mathrm{~min}$ in boiling water. For dilution, $2 \mathrm{~mL}$ distilled water was added to the final reaction mixture. The absorbance was read at $540 \mathrm{~nm}$. The inhibitory effect was calculated by Equation (1). The results were expressed as $\mathrm{IC}_{50}$ (mg GAE/mL). Acarbose (Supelco, Laramie, WY, USA) was used as positive control in order to compare the inhibitory effects.

$$
\text { Inhibition percentage }(\%)=\left[1-\left(\mathrm{Abs}_{\text {sample }}-\mathrm{Abs}_{\text {control-1 }}\right) / \mathrm{Abs}_{\text {control-2 }}\right] \times 100
$$

where the $\mathrm{Abs}_{\text {control-1 }}$ is the result of reaction without adding enzyme, which was replaced for buffer solution, while the mixture of enzyme and starch solution without extract was $\mathrm{Abs}_{\text {control-2. }}$.

\subsection{Statistical Analysis}

All measurements were performed in triplicate, and the results were analyzed using Statistic 13 software (Dell Inc.) [46]. The experimental design data were analyzed by RSM, using the second order polynomial equation. Analysis of variance (ANOVA), test for the lack of fit and coefficient of determination $\left(R^{2}\right)$ were used to verify model significance. The desirability function was applied to determine the operational parameters of extraction that could improve the recovery of bioactive compounds from umbu fruit peel. A $5 \%$ level of significance was employed for all analysis.

\section{Conclusions}

The recovery of bioactive compounds from umbu fruit peel was mainly affected by the ethanol percentage of the extractive solution and extraction temperature. Less apolar binary solvent systems and high temperature provided extracts rich in bioactive compounds. The optimal operational conditions to recover these compounds were $74{ }^{\circ} \mathrm{C}$, $37 \%$ ethanol as solvent, and a solid-liquid ratio of 1:38. Fifteen compounds were identified in the optimized extract, which mainly comprised phenolic acids and flavonoids. This extract showed antioxidant and antimicrobial activities, particularly antibacterial action, and it was able to inhibit $\alpha$-amylase enzyme. Thus, this study allowed the identification of 
optimal operational conditions to obtain a bioactive-rich extract from umbu fruit peel, a residue of processing of this native fruit of Brazil.

Author Contributions: Conceptualization, L.d.O.R. and C.N.K..; methodology, L.d.O.R. and E.P.J.; formal analysis, B.P.d.F., L.d.O.R., H.F.F. and C.M.A.L.; investigation, B.P.d.F., D.d.L.M. and L.d.O.R..; resources, L.d.O.R. and E.P.J.; data curation, L.d.O.R., A.L.S.d.S., D.d.L.M. and B.S.d.A.; writingoriginal draft preparation, L.d.O.R. and B.P.d.F.; writing-review and editing, C.N.K., E.P.J., A.L.S.d.S and D.d.L.M.; supervision, C.N.K. and E.P.J. All authors have read and agreed to the published version of the manuscript.

Funding: This research received no external funding.

Institutional Review Board Statement: Not applicable.

Informed Consent Statement: Not applicable.

Data Availability Statement: Data is contained within the article.

Acknowledgments: The authors acknowledge the support from the National Institute of Technology (INT), Federal University of Rio de Janeiro (UFRJ), Conselho Nacional de Desenvolvimento Científico e Tecnológico (CNPq), Fundação de Amparo à Pesquisa no Estado do Rio de Janeiro (FAPERJ) and Coordenação de Aperfeiçoamento de Pessoal de Nível Superior (CAPES).

Conflicts of Interest: The authors declare no conflict of interest.

\section{References}

1. Genovese, M.I.; da Silva Pinto, M.; de Souza Schmidt Goncalves, A.E.; Lajolo, F.M. Bioactive Compounds and Antioxidant Capacity of Exotic Fruits and Commercial Frozen Pulps from Brazil. Food Sci. Technol. Int. 2008, 14, 207-214. [CrossRef]

2. Santamarina, A.B.; Jamar, G.; Mennitti, L.V.; Ribeiro, D.A.; Cardoso, C.M.; de Rosso, V.V.; Oyama, L.M.; Pisani, L.P. PolyphenolsRich Fruit (Euterpe edulis Mart.) Prevents Peripheral Inflammatory Pathway Activation by the Short-Term High-Fat Diet. Molecules 2019, 24, 1655. [CrossRef] [PubMed]

3. Ribeiro, L.O.; Viana, E.S.; Godoy, R.L.O.; de Freitas, S.C.; Freitas, S.P.; da Matta, V.M. Nutrients and bioactive compounds of pulp, peel and seed from umbu fruit. Cienc. Rural 2019, 49, e20180806. [CrossRef]

4. IBGE. Produção da Extração Vegetal e da Silvicultura-PEVS 2018: Quantidade Produzida na Extração Vegetal; IBGE: Rio de Janeiro, Brazil, 2018. Available online: https://sidra.ibge.gov.br/pesquisa/pevs/quadros/brasil/2018 (accessed on 10 February 2020).

5. Ribeiro, L.O.; Pontes, S.M.; Ribeiro, A.P.O.; Pacheco, S.; Freitas, S.P.; da Matta, V.M. Avaliação do armazenamento a frio sobre os compostos bioativos e as características físico-químicas e microbiológicas do suco de umbu pasteurizado. Braz. J. Food Technol. 2017, 20, e201509. [CrossRef]

6. $\quad$ Banerjee, J.; Singh, R.; Vijayaraghavan, R.; MacFarlane, D.; Patti, A.F.; Arora, A. Bioactives from fruit processing wastes: Green approaches to valuable chemicals. Food Chem. 2017, 225, 10-22. [CrossRef] [PubMed]

7. Beres, C.; Costa, G.N.S.; Cabezudo, I.; da Silva-James, N.K.; Teles, A.S.C.; Cruz, A.P.G.; Mellinger-Silva, C.; Tonon, R.V.; Cabral, L.M.C.; Freitas, S.P. Towards integral utilization of grape pomace from winemaking process: A review. Waste Manag. 2017, 68, 581-594. [CrossRef] [PubMed]

8. Dias, J.L.; Mazzutti, S.; de Souza, J.A.L.; Ferreira, S.R.S.; Soares, L.A.L.; Stragevitch, L.; Danielski, L. Extraction of umbu (Spondias tuberosa) seed oil using $\mathrm{CO}_{2}$, ultrasound and conventional methods: Evaluations of composition profiles and antioxidant activities. J. Supercrit. Fluids 2019, 145, 10-18. [CrossRef]

9. Omena, C.M.B.; Valentim, I.B.; Guedes, G.d.S.; Rabelo, L.A.; Mano, C.M.; Bechara, E.J.H.; Sawaya, A.C.H.F.; Trevisan, M.T.S.; da Costa, J.G.; Ferreira, R.C.S.; et al. Antioxidant, anti-acetylcholinesterase and cytotoxic activities of ethanol extracts of peel, pulp and seeds of exotic Brazilian fruits. Antioxidant, anti-acetylcholinesterase and cytotoxic activities in fruits. Food Res. Int. 2012, 49, 334-344. [CrossRef]

10. Cangussu, L.B.; Fronza, P.; Franca, A.S.; Oliveira, L.S. Chemical Characterization and Bioaccessibility Assessment of Bioactive Compounds from Umbu (Spondias tuberosa A.) Fruit Peel and Pulp Flours. Foods 2021, 10, 2597. [CrossRef] [PubMed]

11. Silva, R.V.; Costa, S.C.C.; Branco, C.R.C.; Branco, A. In vitro photoprotective activity of the Spondias purpurea L. peel crude extract and its incorporation in a pharmaceutical formulation. Ind. Crops Prod. 2016, 83, 509-514. [CrossRef]

12. Gull, A.; Bhat, N.; Wani, S.M.; Masoodi, F.A.; Amin, T.; Ganai, S.A. Shelf life extension of apricot fruit by application of nanochitosan emulsion coatings containing pomegranate peel extract. Food Chem. 2021, 349, 129149. [CrossRef] [PubMed]

13. Tomás-Barberán, F.A.; Espín, J.C. Phenolic compounds and related enzymes as determinants of quality in fruits and vegetables. J. Sci. Food Agric. 2001, 81, 853-876. [CrossRef]

14. Ribeiro, L.O.; Conrado Thomaz, G.F.; de Brito, M.; de Figueiredo, N.; Przytyk Jung, E.; Norie Kunigami, C. Siriguela peels provide antioxidant compounds-rich extract by solid-liquid extraction. J. Food Process. Preserv. 2020, 44, e14719. [CrossRef] 
15. Jesus, M.S.; Genisheva, Z.; Romaní, A.; Pereira, R.N.; Teixeira, J.A.; Domingues, L. Bioactive compounds recovery optimization from vine pruning residues using conventional heating and microwave-assisted extraction methods. Ind. Crops Prod. 2019, 132, 99-110. [CrossRef]

16. Oreopoulou, A.; Tsimogiannis, D.; Oreopoulou, V. Chapter 15-Extraction of Polyphenols from Aromatic and Medicinal Plants: An Overview of the Methods and the Effect of Extraction Parameters. In Polyphenols in Plants, 2nd ed.; Watson, R.R., Ed.; Academic Press: Cambridge, MA, USA, 2019; pp. 243-259. ISBN 978-0-12-813768-0.

17. Ruíz-García, Y.; Beres, C.; Chávez, D.W.H.; Souza, E.F.; Tonon, R.V.; Cabral, L.M.C. Influence of processing conditions on bioactive compound extraction from Vitis vinifera L. var. Alicante Bouschet grape skin. J. Food Sci. Technol. 2019, 56, 1066-1072. [CrossRef] [PubMed]

18. Markom, M.; Hasan, M.; Daud, W.R.W.; Singh, H.; Jahim, J.M. Extraction of hydrolysable tannins from Phyllanthus niruri Linn.: Effects of solvents and extraction methods. Sep. Purif. Technol. 2007, 52, 487-496. [CrossRef]

19. Engels, C.; Gräter, D.; Esquivel, P.; Jiménez, V.M.; Gänzle, M.G.; Schieber, A. Characterization of phenolic compounds in jocote (Spondias purpurea L.) peels by ultra high-performance liquid chromatography/electrospray ionization mass spectrometry. Food Res. Int. 2012, 46, 557-562. [CrossRef]

20. Carvalho Gualberto, N.; Santos de Oliveira, C.; Pedreira Nogueira, J.; Silva de Jesus, M.; Caroline Santos Araujo, H.; Rajan, M.; Terezinha Santos Leite Neta, M.; Narain, N. Bioactive compounds and antioxidant activities in the agro-industrial residues of acerola (Malpighia emarginata L.), guava (Psidium guajava L.), genipap (Genipa americana L.) and umbu (Spondias tuberosa L.) fruits assisted by ultrasonic or shaker extraction. Food Res. Int. 2021, 147, 110538. [CrossRef]

21. Servillo, L.; Giovane, A.; Balestrieri, M.L.; Ferrari, G.; Cautela, D.; Castaldo, D. Occurrence of Pipecolic Acid and Pipecolic Acid Betaine (Homostachydrine) in Citrus Genus Plants. J. Agric. Food Chem. 2012, 60, 315-321. [CrossRef] [PubMed]

22. Wang, J.; de Luca, V. The biosynthesis and regulation of biosynthesis of Concord grape fruit esters, including 'foxy' methylanthranilate. Plant J. 2005, 44, 606-619. [CrossRef]

23. Semwal, R.; Joshi, S.K.; Semwal, R.B.; Semwal, D.K. Health benefits and limitations of rutin-A natural flavonoid with high nutraceutical value. Phytochem. Lett. 2021, 46, 119-128. [CrossRef]

24. Costa, A.G.V.; Garcia-Diaz, D.F.; Jimenez, P.; Silva, P.I. Bioactive compounds and health benefits of exotic tropical red-black berries. J. Funct. Foods 2013, 5, 539-549. [CrossRef]

25. Shahidi, F.; Ambigaipalan, P. Phenolics and polyphenolics in foods, beverages and spices: Antioxidant activity and health effects-A review. J. Funct. Foods 2015, 18, 820-897. [CrossRef]

26. Shrestha, S.; Lee, D.-Y.; Park, J.-H.; Cho, J.-G.; Seo, W.-D.; Kang, H.C.; Jeon, Y.-J.; Yeon, S.-W.; Bang, M.-H.; Baek, N.-I. Flavonoid glycosides from the fruit of Rhus parviflora and inhibition of cyclin dependent kinases by hyperin. J. Korean Soc. Appl. Biol. Chem. 2012, 55, 689-693. [CrossRef]

27. Kanchanapoom, T. Aromatic diglycosides from Cladogynos orientalis. Phytochemistry 2007, 68, 692-696. [CrossRef] [PubMed]

28. Rohde, A.; Morreel, K.; Ralph, J.; Goeminne, G.; Hostyn, V.; De Rycke, R.; Kushnir, S.; Van Doorsselaere, J.; Joseleau, J.-P.; Vuylsteke, M.; et al. Molecular Phenotyping of the pal1 and pal2 Mutants of Arabidopsis thaliana Reveals Far-Reaching Consequences on Phenylpropanoid, Amino Acid, and Carbohydrate Metabolism. Plant Cell 2004, 16, 2749-2771. [CrossRef]

29. Yang, S.-Y.; Du, L.-D.; Lu, Y. Paeonol. In Natural Small Molecule Drugs from Plants; Springer: Singapore, 2018; pp. 439-444, ISBN 978-981-10-8022-7.

30. Bohlinann, F.; Grenz, M. Neue Isopentenyl-acetophenon-Derivate aus Helianthella uniflora. Chem. Ber. 1970, 103, 90-96. [CrossRef]

31. Tao, J.; Morikawa, T.; Ando, S.; Matsuda, H.; Yoshikawa, M. Bioactive Constituents from Chinese Natural Medicines. XI. Inhibitors on NO Production and Degranulation in RBL-2H3 from Rubia yunnanensis: Structures of Rubianosides II, III, and IV, Rubianol-g, and Rubianthraquinone. Chem. Pharm. Bull. 2003, 51, 654-662. [CrossRef]

32. Lima, M.C.; Paiva de Sousa, C.; Fernandez-Prada, C.; Harel, J.; Dubreuil, J.D.; de Souza, E.L. A review of the current evidence of fruit phenolic compounds as potential antimicrobials against pathogenic bacteria. Microb. Pathog. 2019, 130, 259-270. [CrossRef]

33. Dine Tariq Bouhlali, E.; Bammou, M.; Sellam, K.; Benlyas, M.; Alem, C.; Filali-Zegzouti, Y. Evaluation of antioxidant, antihemolytic and antibacterial potential of six Moroccan date fruit (Phoenix dactylifera L.) varieties. J. King Saud Univ.-Sci. 2016, 28, 136-142. [CrossRef]

34. Prasad, B.J.; Sharavanan, P.S.; Sivaraj, R. Efficiency of Oryza punctata extract on glucose regulation: Inhibition of $\alpha$-amylase and $\alpha$-glucosidase activities. Grain Oil Sci. Technol. 2019, 2, 44-48. [CrossRef]

35. Papoutsis, K.; Zhang, J.; Bowyer, M.C.; Brunton, N.; Gibney, E.R.; Lyng, J. Fruit, vegetables, and mushrooms for the preparation of extracts with $\alpha$-amylase and $\alpha$-glucosidase inhibition properties: A review. Food Chem. 2021, 338, 128119. [CrossRef] [PubMed]

36. Laaroussi, H.; Ferreira-Santos, P.; Genisheva, Z.; Bakour, M.; Ousaaid, D.; Teixeira, J.A.; Lyoussi, B. Unraveling the chemical composition, antioxidant, $\alpha$-amylase and $\alpha$-glucosidase inhibition of Moroccan propolis. Food Biosci. 2021, 42, 101160. [CrossRef]

37. Jung, E.P.; Conrado Thomaz, G.F.; de Brito, M.O.; de Figueiredo, N.G.; Kunigami, C.N.; de Oliveira Ribeiro, L.; Alves Moreira, R.F. Thermal-assisted recovery of antioxidant compounds from Bauhinia forficata leaves: Effect of operational conditions. J. Appl. Res. Med. Aromat. Plants 2021, 22, 100303. [CrossRef]

38. Derringer, G.; Suich, R. Simultaneous optimization of several response variables. J. Qual. Technol. 1980, 12, 214-219. [CrossRef]

39. Georgé, S.; Brat, P.; Alter, P.; Amiot, M.J. Rapid Determination of Polyphenols and Vitamin C in Plant-Derived Products. J. Agric. Food Chem. 2005, 53, 1370-1373. [CrossRef] 
40. Zhishen, J.; Mengcheng, T.; Jianming, W. The determination of flavonoid contents in mulberry and their scavenging effects on superoxide radicals. Food Chem. 1999, 64, 555-559. [CrossRef]

41. Gião, M.S.; González-Sanjosé, M.L.; Rivero-Pérez, M.D.; Pereira, C.I.; Pintado, M.E.; Malcata, F.X. Infusions of Portuguese medicinal plants: Dependence of final antioxidant capacity and phenol content on extraction features. J. Sci. Food Agric. 2007, 87, 2638-2647. [CrossRef] [PubMed]

42. Hidalgo, M.; Sánchez-Moreno, C.; de Pascual-Teresa, S. Flavonoid-Flavonoid interaction and its effect on their antioxidant activity. Food Chem. 2010, 121, 691-696. [CrossRef]

43. Benzie, I.F.F.; Strain, J.J. The Ferric Reducing Ability of Plasma (FRAP) as a Measure of "Antioxidant Power": The FRAP Assay. Anal. Biochem. 1996, 76, 70-76. [CrossRef] [PubMed]

44. Wang, M.; Carver, J.J.; Phelan, V.V.; Sanchez, L.M.; Garg, N.; Peng, Y.; Nguyen, D.D.; Watrous, J.; Kapono, C.A.; Luzzatto-Knaan, T.; et al. Sharing and community curation of mass spectrometry data with Global Natural Products Social Molecular Networking. Nat. Biotechnol. 2016, 34, 828-837. [CrossRef] [PubMed]

45. Meng, Y.; Su, A.; Yuan, S.; Zhao, H.; Tan, S.; Hu, C.; Deng, H.; Guo, Y. Evaluation of Total Flavonoids, Myricetin, and Quercetin from Hovenia dulcis Thunb. As Inhibitors of $\alpha$-Amylase and $\alpha$-Glucosidase. Plant Foods Hum. Nutr. 2016, 71, 444-449. [CrossRef] [PubMed]

46. Statistica 13, version 13; Data analysis software system; Dell Inc.: Tulsa, OK, USA, 2015. 